\title{
Do Institutions Not Matter in China? Evidence from Manufacturing Enterprises
}

\author{
Yi Lu, Ivan P.L. Png, and Zhigang Tao*
}

May 2008

Revised, February 2010

\begin{abstract}
This study addresses the apparent puzzle that China achieved spectacular economic performance despite weak institutions. Using a World Bank survey of 1,566 manufacturing enterprises in 18 Chinese cities, we investigated whether property rights protection mattered for enterprise performance. We found that property rights protection had a positive and statistically significant impact on enterprise productivity. Two-step GMM estimation and the difference-in-differences estimation further established the causal impacts of property rights protection on enterprise productivity. These findings were robust to various controls, outliers, and alternative measures of productivity and property rights protection.
\end{abstract}

Key Words: Institutions, Property Rights, Productivity, External Dependence, Entry Barriers

JEL Codes: O43 P48 D21 L25 O12

* Lu and Tao, University of Hong Kong; Png, National University of Singapore. We are grateful to the University of Hong Kong, Hong Kong Research Grants Council, and the Lim Kim San Professorship for financial support. 


\section{Introduction}

Numerous cross-country and within-country studies have shown that institutions are fundamental to economic performance (Besley, 1995; Knack and Keefer, 1995, 1997; Mauro, 1995; Hall and Jones, 1999; La Porta, Lopez-de-Silanes, Shleifer, and Vishny, 1999; and Acemoglu, Johnson, and Robinson, 2001, 2002). Indeed, the World Bank and International Monetary Fund have stressed the importance of sound institutions in the growth of developing economies (Carothers 2006; Economist, March 15, 2008).

However, the record of the Chinese economy over the past thirty years seems to contradict the scholarly finding that institutions are essential to economic performance. Until recently, China provided little formal protection of private property, e.g., protection of private properties was not written into China's Constitution until 2004 (Blanchard and Kremer, 1997; Rodrik, 2004a and 2004b; Allen, Qian, and Qian, 2005; Economist, March 15, 2008). Nevertheless, China's economic performance has been nothing less than spectacular.

Did institutions really not matter for the performance of the Chinese economy? One possible explanation is that de facto institutional quality varied widely across China (Du, Lu, and Tao, 2008; World Bank, 2008; Lu and Tao, 2009a), and that China's economic development was concentrated in those regions where institutions are reasonably good. ${ }^{1}$ This might possibly explain the apparent contradiction between the poor state of China's institutions and the country's spectacular economic performance at the macro level.

Here, using detailed data at the enterprise level, we were able to address the China puzzle (i.e., that institutions were not important for economic performance) at the microeconomic level. We focused on the protection of private properties, which is arguably the most important aspect of institutions (North, 1991; Acemoglu, Johnson, and Robinson, 2001; Besley and Ghatak, 2009). Specifically, we investigated whether enterprises enjoying better property rights protection exhibited better performance.

\footnotetext{
${ }^{1}$ Another possible explanation is that the importance of institutions varied across industries and that China's economic development was concentrated among industries for which institutions are less important.
} 
We drew on the Survey of Chinese Enterprises, conducted by the World Bank with the Enterprise Survey Organization of China in early 2003. ${ }^{2}$ The data set covered 1,566 enterprises drawn from 9 manufacturing industries and 18 cities. To measure enterprise performance, we used labor productivity, i.e., the logarithm of output per worker of an enterprise, and total factor productivity estimated using either the panel fixed-effect method or the methodology developed by Levinsohn and Petrin (2003). Our focus on productivity was motivated by Acemoglu, Johnson, and Robinson (2001), who studied the impact of institutions on income per capita, and interpreted the results as providing implications for the impact of institutions on economic growth.

The quality of property rights protection can be measured by the effectiveness of various means for addressing disputes associated with private properties. One of the means for resolving disputes is court litigation, and the other is to seek help from the state. ${ }^{3}$ To measure the effectiveness of court litigation, we used the perceived likelihood that the legal system will uphold contract and property rights in business disputes. To measure the effectiveness of seeking help from the state, we used the perceived share of government officials oriented toward helping firms.

Recent studies in political economy pointed out that the role of state in codifying and protecting private properties is more important than court litigation (Besley and Ghatak, 2009). This is especially so in the case of China. The legal institutions, which were not needed at all under China's central planning economy prior 1978, were too slow to adapt to complicated and fast-changing environment, and were short of autonomous enforcement powers in China (e.g., Fan, 1985; Lieberthal and Oksenberg, 1988; Zhao, 1989; Li, Zhang, and Wang, 1990; Clarke, 1991). In contrast, even after thirty years of economic reform, government officials remained heavily involved in interpreting and enforcing national laws and ordinances. As a result, we focused mainly on the effectiveness of seeking help from the state as the measure of property rights protection, and used the effectiveness of court litigation as an alternative measure of property rights protection in the robustness check.

\footnotetext{
${ }^{2}$ The data set has recently been used by Cull and Xu (2005), Ayyagari, Demirgüç-Kunt, and Maksimovic (2007), and Dong and Xu (2009), among others.

${ }^{3}$ These two means for resolving disputes are formally called litigation through courts and regulatory state by Djankov, Glaeser, La Porta, Lopez-de-Silanes, and Shleifer (2003).
} 
We found that an enterprise perceiving better protection of property rights had a statistically significantly higher productivity. In order to conclude that this relation was indeed due to a causal impact, that stronger protection of property rights increased productivity, we ruled out a number of alternative explanations and conducted various robustness checks.

First, we checked that our finding was not driven by some omitted variables. We introduced a host of covariates related to CEO characteristics (such as human capital and political capital) and enterprise characteristics (such as enterprise size, enterprise age, private ownership percentage, and skilled labor ratio) used in previous research, as well as industry and city dummies. Our result was robust to the inclusion of these controls. It is also important to note that the positive impact of property rights protection on productivity became smaller with the inclusion of city dummies, which supports our earlier conjecture that part of the China puzzle could be explained by the concentration of growth in particular geographical areas with better institutions.

Second, we worried that our finding might still be biased due to some unobserved characteristic correlated with both expropriation and productivity. To address such potential endogeneity, we used the two-step Generalized Method of Moments (GMM) estimation with two alternative instruments for property rights protection, viz., the average assessment of property rights protection by enterprises of other industries located in the same city, and the logarithm of population in the respective city around 1918-19. The two-step GMM estimates reinforced our findings that property rights protection had a positive and significant causal impact on productivity.

Third, we applied the difference-in-differences method of Rajan and Zingales (1998). Following Blanchard and Kremer (1997) and Rajan and Subramanian (2007), we used the number of suppliers to measure, for each enterprise, its reliance on the external environment. We found that enterprises which were more reliant on the external environment (in the sense of using more external suppliers) exhibited relatively higher productivity in cities with stronger property rights protection. In addition, following Djankov, La Porta, Lopez-de-Silanes, and Shleifer (2002), we used the number of days to register a new business to measure, for each enterprise, the level of entry barriers. We found that enterprises which faced lower entry barriers exhibited relatively higher productivity in cities with stronger property rights protection. 
In further robustness checks, we explored alternative measures of productivity and property rights protection, used quantile regressions to deal with possible impact of outlying observations, and investigated whether the results were biased due to the inclusion of state-owned enterprises.

In a recent study, Fang and Zhao (2007) also addressed the China puzzle in a cross-section of 47 Chinese cities. They found that property rights did have a significant effect on income, as measured by log GDP per capita. They used city-level measures of property rights from surveys by Ni et al. (2004, 2005) instrumented by a historical measure, viz., lower primary enrolment in missionary schools in 1919. Our study differed from that of Fang and Zhao (2007) in two important ways: (i) our study was at the level of individual enterprises rather than cities, hence revealing possible differences among enterprises and between industries within the same city; and (ii) our study did not rely on just one identification strategy -- we applied three estimation methods, specifically, ordinary least squares with multiple controls, the two-step generalized method of moments with two alternative instruments, and the Rajan and Zingales (1998) difference-in-differences method of exploiting differences in external dependence and entry barriers. 4

The remainder of the paper is structured as follows. Section 2 introduces the data and variables for the empirical study, while Section 3 presents the main results. The paper concludes with Section 4.

\section{Data and Variables}

Our empirical analysis drew on data from the Survey of Chinese Enterprises (SCE), conducted by the World Bank in cooperation with the Enterprise Survey Organization of China in early 2003. For balanced representation, the SCE selected 18 cities from five regions of China: Northeast - Benxi, Changchun, Dalian, and Haerbin; Coastal region Hangzhou, Jiangmen, Shenzhen, and Wenzhou; Central China - Changsha, Nanchang,

\footnotetext{
4 With regard to Fang and Zhao's instrument, the enrolment in lower primary Christian missionary schools in 1919 was only 7.2 out of 10000 people. As might be expected, this small proportion was a weak predictor of the quality of institutions. Indeed, the value of the $F$-statistic in their first-stage regression was 7.77, which falls below the critical value of 10 (Staiger and Stock 1997).
} 
Wuhan, and Zhengzhou; Southwest - Chongqing, Guiyang, Kunming, and Nanning; and Northwest - Lanzhou and Xi’an.

In each city, the SCE randomly sampled 100 or 150 enterprises from 9 manufacturing industries (garment and leather products, electronic equipment, electronic parts making, household electronics, auto and auto parts, food processing, chemical products and medicine, biotech products and Chinese medicine, and metallurgical products), and 5 service industries (transportation service, information technology, accounting and non-banking financial services, advertisement and marketing, and business services). The total number of enterprises surveyed was 2,400.

The SCE comprised two parts. One was a general questionnaire directed at the senior management seeking information about the enterprise, such as innovation, product certification, marketing, relations with suppliers and customers, access to markets and technology, relations with government, labor, infrastructure, international trade, finance and taxation, and the CEO and board of directors. The other questionnaire was directed at the accountant and personnel manager, covering ownership, various financial measures, and labor and training. Most of the information from the first part of SCE pertained to the survey year - 2002, while the second part pertained to the period 2000-2002.

We were concerned with the impact of institutions on the productivity of the enterprise. As manufacturing enterprises generally have more complicated supply chains than those of service enterprises, and furthermore their productivity is easier to measure and interpret, we focused on a subset of 1,566 manufacturing enterprises.

Our dependent variable was enterprise productivity. One measure was labor productivity, which was calculated as the logarithm of total output divided by total employment. ${ }^{5}$ An alternative measure would be total factor productivity (TFP), estimated using either the panel fixed-effect method or the Levinsohn and Petrin (2003) methodology. As information about material inputs was fragmentary (missing in more

\footnotetext{
${ }^{5}$ Note that output was a revenue-based measure rather than quantity-based. In order to recover the quantity-based measure of output, we need the enterprise-level price to deflate the revenue. Since enterprise-level prices are rarely available, a commonly-used way in the literature is to deflate the revenue-based output by the industry average price index. This procedure, however, introduces omitted price bias (Klette and Griliches, 1996). One way to address this problem is to assume a constant elasticity of substitution demand function and include industry total output as an additional control (Klette and Griliches, 1996; De Loecker, 2009). Accordingly, in most of our regressions, we included industry dummies, which, in a cross-section analysis, was essentially similar to the method of recovering the quantity-based output.
} 
than $25 \%$ of the sample), we used labor productivity for the main analysis, and total factor productivity as a robustness check.

Table 1 reports summary statistics of the data, while Table 2 reports bivariate correlations. Referring to Table 1, the mean value of labor productivity was 4.322 $( \pm 1.562)$ thousand Yuan per worker, while TFP was $4.151( \pm 1.077)$, as estimated by the fixed-effect method, and 3.042 ( \pm 0.953$)$, as estimated by the Levinsohn and Petrin (2003) method.

Our key explanatory variable was the quality of property rights protection, which is arguably the most important aspect of institutions (North, 1991; Acemoglu, Johnson, and Robinson, 2001; Besley and Ghatak, 2009). When there is a violation of private properties (say, a buyer defaults on his payment after receiving a good from a seller, or the user of an asset refuses to pay the owner of the asset for usage), there are two ways through which the owner of the good or the asset can protect his property rights. One is to sue the violator in the court (court litigation), and the other is to seek help from the state.

Recent studies in political economy pointed out that the role of state in codifying and protecting private properties can be more important than court litigation. For example, Besley and Ghatak (2009) argue that "while historically non-state actors have played a key role in the creation and enforcement of rights, in the modern world weak property rights boils down to the way that the state functions.”

This is especially so in the case of China where legal institutions were weak but the state maintained strong control of the economy even after thirty years of transition towards a market economy. Due to the substantial variations in endowments, socioeconomic development and culture across regions as well as fast-changing environments, laws and national ordinances enacted in China tend to be sketchy and incomplete. In this situation, the power to interpret the existing laws and national ordinances, to adapt them to the changing circumstances, and to extend their application to new cases constitutes the cornerstone of property rights protection (Pistor and $\mathrm{Xu}$, 2002). 
Courts appear too slow to adapt to changes because they are designed to be reactive enforcers in the sense that they would not initiate legal proceedings but only respond to the initiation of another party. Moreover, in China, courts lack autonomous powers of enforcement, and so, the enforcement of rulings hinges upon the cooperation of the state organizations such as the public security bureaus (e.g., Fan, 1985; Lieberthal and Oksenberg, 1988; Zhao, 1989; Li, Zhang, and Wang, 1990; Clarke, 1991). In contrast, government officials can exercise de facto lawmaking power by adapting rules to changing situations on a continuous basis and initiating enforcement procedures. They can proactively enforce contracts by interpreting laws and national ordinances, monitoring behavior, launching investigation, and sanctioning actions on their own initiative (Du and $\mathrm{Xu}, 2009)$.

As a result, we focus mainly on the effectiveness of seeking help from the state as the measure of property rights protection. Specifically, we constructed the measure, Property Rights, as the response to the question, "Among the government officials that your firm regularly interacts with, what is the share that is oriented toward helping rather than hindering firms?” The response varied from $0 \%$ to $100 \%$, with mean of $35.5 \%$ ( $\pm 32.0 \%$ ), and where a higher value represented better protection of property rights. Cull and Xu (2005) and Lin, Lin, and Song (2009) used this same measure to study the impacts of property rights on reinvestment and R\&D investment, respectively.

In a robustness check, we used the effectiveness of litigation (denoted by Litigation) as an alternative measure of property rights protection. Specifically, it was measured as the response to the question, "What's the likelihood that the legal system will uphold my contract and property rights in business disputes?” The response varied from $0 \%$ to $100 \%$, with a mean value of $63.4 \%( \pm 38.9 \%)$, and where a higher value represented better protection of property rights.

As a preliminary, we verified that the degree of property rights protection was indeed grounded in geographical differences. Appendix A reports a regression of Property Rights on industry and city dummies, along with a list of control variables related to enterprise and CEO characteristics. Evidently, there was substantial and statistically significant variation in property rights protection across Chinese cities. ${ }^{6}$ This is because, even though China is a unitary state with uniform laws and national ordinances, the de facto property rights protection hinges upon the interpretation and

\footnotetext{
${ }^{6}$ Apparently, however, there was no significant systematic variation in property rights protection across industries.
} 
enforcement of laws and national ordinances by the regional governments. Our measure, Property Rights, was based on the enterprise's overall perception of the effectiveness of seeking help from the state, thus capturing the de facto, rather than the de jure, protection of property rights.

In the empirical analysis, we also controlled for other factors that might possibly affect enterprise productivity, including enterprise and CEO characteristics that were variously used in previous studies of investment and productivity (Cull and Xu 2005; $\mathrm{Li}$, Meng, Wang, and Zhou 2008), as well as industry and city dummies. The enterprise characteristics included enterprise size (measured by the logarithm of employment in the previous year), enterprise age (measured by the logarithm of years of establishment up to the end of 2002), private ownership percentage (measured by the share of equity owned by parties other than government agencies), and skilled labor ratio (measured by the ratio of skilled labor in the total employment in the previous year). The CEO characteristics included measures of human capital - CEO education (years of schooling), CEO tenure (years as CEO), and deputy CEO previously (an indicator of whether the CEO had been the deputy CEO of the same enterprise before becoming CEO); and measures of political capital - government cadre previously (an indicator of whether the CEO had previously been a government official), party member (an indicator of whether the CEO was a member of the Chinese Communist Party), and CEO government appointed (an indicator of whether the CEO was appointed by the government). Finally, we included dummy variables for industry and city to account for possible differences in enterprise productivity across industries and cities.

In investigating the impact of property rights protection on enterprise productivity, the enterprise-level perception of property right protection should yield more precise estimates than the city-average perception. Enterprise-level productivity depends on various organizational and strategic decisions - including who to engage as investors and partners, whether to use capital or labor-intensive modes of production, how much to outsource the production of inputs, and whether to distribute through direct or indirect channels - all of which depend on the management's perception of property rights protection.

However, using an enterprise-level measure of property rights may introduce endogeneity in the form of omitted variables bias or reverse causality. For example, even with many controls included, there could still be some uncontrolled variables, such as favorable individual treatment, which correlate with both enterprise-level measure of 
property rights protection and enterprise performance. And it could also be possible that more productive enterprises have more resources, such as more political connections, which lead to more secure de facto property rights protection.

To address these endogeneity issues, we applied two-step Generalized Method of Moments (GMM) estimation using two alternative instruments. One instrument was the average response by enterprises of other industries located in the same city regarding the quality of property rights protection. The other instrument was the logarithm of population in the respective city around 1918-19. We discuss the identification strategy using these instruments in Section 3.2.

As a further robustness check, we applied the difference-in-differences estimation method of Rajan and Zingales (1998). First, we tested whether property rights protection had differential impacts on enterprises with different degrees of dependence on the external environment. Following Blanchard and Kremer (1997: 1116) and Rajan and Subramanian (2007: 323), we used the number of suppliers to operationalize reliance on the external environment. ${ }^{7}$ An enterprise with more suppliers would have a more complex production system and supply chain, hence would be more reliant on the external environment. This measure showed substantial variation, with a mean value of 42 ( \pm 199 ). Second, following McMillan and Woodruff (2002), we tested whether property rights protection had differential impacts on enterprises facing different levels of entry barriers. Following Djankov, La Porta, Lopez-de-Silanes, and Shleifer (2002), we used the number of days to register a new business to operationalize the level of entry barriers. This measure also exhibited substantial variation, with a mean value of 8.817 $( \pm 11.811)$.

\section{Empirical Analysis}

\subsection{OLS Estimation}

To investigate the impact of property rights protection on enterprise productivity, we used the following basic specification:

${ }^{7}$ Owing to data limitations, Blanchard and Kremer (1997) and Rajan and Subramanian (2007) used industry-level measures of reliance. By contrast, our measure was at the enterprise level. 


$$
y_{\text {eic }}=\mu+\alpha R_{\text {eic }}+\varepsilon_{\text {eic }},
$$

where $y_{\text {eic }}$ is enterprise productivity (i.e., Labor Productivity or Total Factor Productivity) of enterprise, $e$, belonging to industry, $i$, and located in city, $c$; $\mu$ is a constant; $R_{\text {eic }}$ measures the quality of property rights protection as reported at the enterprise level (i.e., Property Rights Protection or Litigation); and $\varepsilon_{\text {eic }}$ is an independently and identically distributed error with a normal distribution and mean zero. To deal with possible heteroskedasticity, we used the robust standard error clustered at the industry-city level. ${ }^{8}$

Table 3, column (i), presents OLS estimates of specification (1). Property rights protection had a positive and statistically significant impact on labor productivity. To gauge the economic significance of this result, we calculated that a one standard deviation increase in property rights protection was associated with an increase of $0.511 \mathrm{x}$ $0.320=0.164$ in labor productivity or $3.8 \%$ relative to the mean labor productivity. This impact is reported in the last row of Table 3.

Do these results truly reflect the causal effect of property rights protection on labor productivity? An immediate concern is that the estimates could be biased owing to the omission of relevant variables. Then,

$$
E\left(R_{\text {eic }} \cdot \varepsilon_{\text {eic }}\right) \neq 0 .
$$

To the extent that we can find a comprehensive set of control variables, $X_{\text {eic }}$, and coefficients, $\gamma$, such that the residual error term, $\eta_{e i c} \equiv \varepsilon_{e i c}-X_{e i c} \cdot \gamma$, is not correlated with $R_{\text {eic }}$, then we can isolate the causal effect of property rights protection on labor productivity (Goldberger, 1972; Barnow et al., 1981). We specified, as controls, CEO characteristics (human capital and political capital), enterprise characteristics (enterprise size, enterprise age, private ownership percentage, and skilled labor ratio), industry dummies, and city dummies. Accordingly, the specification was:

\footnotetext{
${ }^{8}$ The standard errors for micro-level data need to be adjusted for the possibility that error terms could be correlated within a cluster (Liang and Zeger, 1986). However, when the number of clusters is small (specifically, fewer than 42), the clustered standard errors could be misleading (e.g., Wooldridge, 2003, 2006a; Angrist and Pischke, 2009). As our study includes just 18 cities and 9 industries, we did not use the clustered standard errors at the city-level or industry-level. Instead, we used standard errors clustered at the industry-city level.
} 


$$
y_{\text {eic }}=\mu+\alpha R_{\text {eic }}+X_{e i c}{ }^{\prime} \cdot \gamma+\eta_{\text {eic }}
$$

Table 3, columns (ii)-(vi), reports the results. To avoid issues of multicollinearity and poor controls (Angrist and Pischke, 2009), we included the control variables in a stepwise fashion. Among enterprise characteristics, the coefficient of enterprise size was positive and significant in all specifications. Apparently, enterprises with larger workforces exhibited relatively higher labor productivity, suggesting the presence of economies of scale. This would be consistent with evidence of local protectionism within China (Young, 2000; Bai, Du, Tao, and Tong, 2004), which would result in production at sub-optimal scale.

The coefficient of enterprise age was negative and significant. Enterprises with longer history exhibited relatively lower labor productivity. This is consistent with the experience of China's economic reform that new firms drove economic development, particularly by ending the monopoly of state enterprises (McMillan and Woodruff, 2002).

The coefficient of skilled labor ratio was positive and significant. Apparently, enterprises with more skilled labor exhibited higher labor productivity. This is consistent with the importance of skilled labor in less developed countries (e.g., Acemoglu and Zilibotti, 2001), and the observed shortage of skilled labor in China (Asian Development Bank, 2003; Wang, 2006).

Among the CEO characteristics, the coefficient of CEO education was positive and significant, while the coefficient of government appointment was negative and significant in all specifications. Previous research into education and growth focused on the impact of the education of the workforce (e.g., Barro, 2001). The novelty of our result is the impact of the CEO's education on the overall productivity of the enterprise. The negative impact of government appointment is a phenomenon that would be unique to a transitional economy. It is consistent with the view that government appointment of CEOs is based on political considerations rather than managerial talent.

With respect to the central issue, the coefficient of property rights protection was positive and statistically significant in all specifications, ranging from 0.245 to 0.448 . Accordingly, we infer that our finding that property rights protection increased labor productivity was robust to the various controls. 
It is important to note that the magnitude of the impact of property rights protection on enterprise productivity was about $21 \%$ lower with the inclusion of city dummies. This is consistent with our preliminary analysis, reported in Appendix A, that a substantial part of the variation of property rights protection across enterprises was due to variation across cities. It is also consistent with our conjecture that part of the China puzzle (that institutions seem unimportant for economic performance) could be explained by the concentration of economic activities in geographic areas with better institutions.

\subsection{GMM Estimation}

While we included a comprehensive set of control variables, $X_{\text {eic }}$, it could still be possible that the residual error, $\eta_{e i c}$, even including the controls $X_{\text {eic }}$, might be correlated with the index of property rights protection, $R_{\text {eic }}$, so that $E\left(R_{e i c} \cdot \eta_{\text {eic }}\right) \neq 0$, in which case the estimates would be biased. To address this endogeneity issue, we applied the twostep GMM using two alternative instruments for property rights protection.

\subsubsection{Instrumental Variable 1: Average Perceived Property Rights Protection Among Other Industries in Same City}

Following the recent literature on empirical industrial organization (e.g., Berry, Levinsohn, and Pakes, 1995; Nevo, 2000, 2001), we first used the average response of enterprises belonging to other industries and located in the same city regarding the quality of property rights protection as an instrument for the enterprise-level perception of property rights protection.

Note that with the inclusion of industry and city dummies, the only possible remaining omitted variables were at the industry-city level or individual enterprise-level. The average perceived property rights protection among enterprises belonging to other industries located in the same city should not be correlated with industry-city level or individual enterprise-level characteristics, so that the exclusion condition for two-step GMM estimation would be satisfied. ${ }^{9}$

Meanwhile, the average perception of property rights protection among enterprises belonging to other industries located in the same city should be negatively

\footnotetext{
${ }^{9}$ As reported below, we showed formally that the exclusion condition was satisfied.
} 
correlated with the enterprise-level perception of property rights protection. With city dummies controlling for the absolute levels of property rights protection across different cities, the enterprise-level and other industry property rights protection variables are deviations from the city averages and so, should sum to zero. Intuitively, the level of property rights protection reflects the behavior of government officials and related parties, for example, the time and effort devoted by government officials to protecting private property. As the city dummies controlled for the total time and effort that government officials used to protect private properties across different cities, the inter-industry difference within a city reflected the allocation of time and effort across different industries within the city. Thus, since the officials' total time and effort is limited, it seems reasonable that if officials put more time and effort in protection of private property in one industry, then they would have less for other industries. In other words, the instrumental variable should be negatively correlated with the endogenous explanatory variable, and so, the relevance condition for the two-step GMM estimation would be satisfied.

-- Table 4 ---

Table 4, columns (i)-(ii), reports the two-step GMM estimates. We included the various control variables -- CEO characteristics, enterprise characteristics, industry dummies, and city dummies in all estimates. Regarding the relevance condition for a valid instrument, the correlation between the instrument and the endogenous variable was negative and highly significant (as shown in column (i)), consistent with the intuition presented above. Moreover, the Anderson canonical correlation LR statistic and the Cragg-Donald Wald statistic provided further support for the satisfaction of the relevance condition. We also checked for a weak instrument, which was ruled out by the large Shea partial $R^{2}$ and the Cragg-Donald $F$-statistic. ${ }^{10}$

With respect to the central issue, the coefficient of property rights protection, instrumented by the average perceived property rights protection among enterprises belonging to other industries located in the same city, was positive and statistically significant. The coefficient was 1.331 ( \pm 0.766), which was almost four times larger than the OLS estimate. Correspondingly, the estimated impact of a one standard deviation increase in property rights protection on labor productivity was $9.9 \%$ of the mean labor productivity, which was almost four times larger than the OLS estimate. Apparently, any

${ }^{10}$ The F-statistic was significantly above the critical value of 10 (Staiger and Stock 1997). 
bias due to endogeneity served to bias the impact of property rights protection downward rather than upward. Another possibility is that there were measurement errors associated with the measure of property rights protection, which biased the OLS estimates downward towards zero.

To formally check that the instrumental variable satisfied the exclusion condition, i.e., was not correlated with the residual error, $\eta_{e i c}$, we conducted a test following Acemoglu, Johnson, and Robinson (2002). The premise for the test is that, if the instrumental variable affects labor productivity only through property rights protection, then instrumental variable should not have any significant impact on labor productivity conditional on property rights protection. Indeed, as shown in Table 4, columns (iii)-(iv), the instrumental variable had a positive and significant impact on labor productivity, but the effect vanished with the inclusion of the explanatory variable, Property Rights

\section{Protection.}

\subsubsection{Instrumental Variable 2: City Population Around 1918-19}

Motivated by the literature on economic institutions (La Porta, Lopez-de-Silanes, Shleifer, and Vishny, 1997, 1998; Acemoglu, Johnson, and Robinson, 2001, 2002), we developed a historical proxy, $R_{c, h i s t o r y}$, for the general level of property rights protection in each city. A historical proxy should not be correlated with unobserved characteristics of enterprises in 2002, and hence should satisfy the exclusion condition, $E\left(R_{c, h i s t o r y} \cdot \eta_{e i c}\right)=0$.

The historical proxy of the city's property rights protection would arguably be correlated with the contemporary level of property rights protection, $E\left(R_{c, h i s o t r y} \cdot R_{c}\right) \neq 0$. A large body of empirical work has shown that differences in economic institutions across countries persist over time (Young, 1994; Acemoglu, Johnson, and Robinson, 2001, 2002; La Porta, Lopez-de-Silanes, and Shleifer, 2008) ${ }^{11}$ Some reasons include the

\footnotetext{
11 “[A]lthough we commonly described the independent polities as 'new states', in reality they were successors to the colonial regime, inheriting its structures, its quotidian routines and practices, and its more hidden normative theories of governance” (Young, 1994: 283). Acemoglu, Johnson, and Robinson (2001) discussed three mechanisms that would result in institutional persistence: (i) it was costly to set up institutions that restricted government expropriation; (ii) the formation of institutions was influenced by the elites which were quite persistent; (iii) the established institutions would induce irreversible investments that were complementary to the existing institutions, which made people more willing to support those institutions. La Porta, Lopez-de-Silanes, and Shleifer (2008) argued that cultures, religions and ideologies are likely to persist over time despite regime changes.
} 
persistence of culture, beliefs, and ideologies across generations (e.g., Bisin and Verdier, 2000; Dohmen, Falk, Huffman, and Sunde, 2006; Tabellini, 2007a, 2007b, 2009).

Specifically, with regard to China, there is also evidence that geographical differences in economic institutions have persisted over time, despite radical changes in the political regime, beginning with the collapse of the Qing Dynasty in the early 20th century. For example, areas with higher industrial and commercial activities in the preCommunist era were faster and more effective in market reform in recent years (e.g., Zhu, 2001; Fu, 2003). And areas with larger population during the Qing Dynasty continue to be relatively more prosperous in the Communist era (e.g., $\mathrm{Li}$ and $\mathrm{Lu}, 2009$ ).

To proxy for the historical level of city's property rights protection, we used the logarithm of population in the respective city around 1918-19. Absent systematic national censuses, our source of data on city populations was a study conducted by the China Continuation Committee, an organization of Protestant churches and missions (Special Committee on Survey and Occupation of China Continuation Committee, 1987). The Committee based its estimates on various sources, including reports by police commissioners and local missions, the 1910 census by the Ministry of the Interior, and a 1919-20 census by the Post Office. Given the fragmentary state of information on China's population (Chen 1947; Ho 1959), we believe that the China Continuation Committee study is a reasonable source for the population of Chinese cities at the time.

China was besieged by foreign powers in the late 1800s and early 1900s. During the same period, it was beset by civil war. Absent a strong central government and in the face of financial difficulties, expropriation of private property by regional governments was widespread (Wu, 1955; Li, Li, Li, Yang, and Gong, 1994; Dong, Zhang, and Jiao, 2000). Given geographical mobility, especially among wealthy people, the population of a city in 1918-19 could reasonably reflect the state of property rights protection at that time, with a larger population indicating better property rights protection. Appendix B provides the detailed rationale for this proxy.

-- Table 5 ---

Table 5, column (i), reports the two-step GMM estimates using the logarithm of population in the city around 1918-19 as the instrument for property rights protection. We included the various control variables -- CEO characteristics, enterprise characteristics, industry dummies, and city characteristics -- in all estimates. With regard to the relevance condition for an effective instrument, the logarithm of population in the city 
around 1918-19 was highly and positively correlated with the enterprise perception of property rights protection. The condition was further confirmed by the Anderson canonical correlation LR statistic and the Cragg-Donald Wald statistic. Any concern about a weak instrument was ruled out by the large Shea partial $R^{2}$ and the Cragg-Donald $F$-statistic.

The two-step GMM estimated coefficient of property rights protection, as instrumented by the logarithm of population in China's respective city around 1918-19, was 4.787 ( \pm 1.487$)$, which was statistically significant. It was even larger than the estimates using the average perceived property rights protection by enterprises of other industries located in the same city as the instrument.

The identification strategy using the logarithm of population in the city around 1918-19 as the instrumental variable relied on the exclusion restriction, specifically, the assumption that the instrument should not affect labor productivity through channels other than property rights protection. Intuitively, we did not expect the early $20^{\text {th }}$ century population to be correlated with enterprise-level characteristics in 2002. However, since the instrumental variable was at the city-level, precluding the use of city dummies, there could be some city-level omitted variables through which the instrumental variable might affect labor productivity. While we were not able to check the exclusion restriction assumption with certainty as the data did not allow us to control for all city-level variables, we investigated several city-level factors that might be of particular concern.

First, the number of population in the city around 1918-19 might be negatively determined by the severity of the crime rate, which mjght persist over time. To control for this possibility, we included a proxy for the contemporaneous crime rate, specifically, the average losses due to theft among other enterprises situated in the same city.

Second, the population in the city around 1918-19 might be correlated with clustering of suppliers in the city, which might persist over time. To control for this possibility, we included a proxy for the contemporaneous clustering of suppliers in each city, which was measured by the average ratio of suppliers located in the same city over the total number of suppliers among other enterprises situated in the city.

Third, the population in the city around 1918-19 might reflect the behavior of government officials and elites towards protection of the local economy in the city, which might persist over time. To control for this possibility, we included a proxy for the contemporaneous degree of local protectionism in each city, which was measured by the 
average ratio of state ownership among other enterprises situated in the city, following Bai et al. (2004) and Lu and Tao (2009b).

We, stepwisely, included the above three city-level variables, along with the controls for CEO and enterprise characteristics, industry dummies and city characteristics. Table 5, columns (ii)-(iv), reports the results. It is clear that our central findings regarding the importance of property rights protection for labor productivity was robust to the inclusion of these additional controls.

\subsection{Difference-in-Differences Estimation}

As an alternative way to check the causal impact of property rights protection on enterprise productivity, we applied the difference-in-differences estimation strategy pioneered by Rajan and Zingales (1998). This approach establishes causality by focusing on the details of theoretical mechanisms through which property rights protection may affect enterprise productivity.

Our first hypothesis is that the impact of property rights protection on productivity varies across enterprises according to their degree of reliance on the external environment. The impact of private property protection would be higher on an enterprise with a greater reliance on the external environment. Thus, it is reasonable to expect that enterprises which are more reliant on the external environment should exhibit relatively higher labor productivity in cities with stronger property rights protection.

Following Blanchard and Kremer (1997) and Rajan and Subramanian (2007), we used the number of suppliers to measure, for each enterprise, its reliance on the external environment. Accordingly, we estimated the following equation:

$$
y_{e i c}=\mu+\alpha R_{e i c}+\beta S_{e i c}+\delta R_{e i c} \cdot S_{e i c}+X_{e i c}{ }^{\prime} \cdot \gamma+\eta_{e i c},
$$

where $S_{\text {eic }}$ measures the reliance on the external environment at the enterprise level (Supplier); $X_{\text {eic }}$ is a vector of controls (CEO and enterprise characteristics, industry dummies, and city dummies); and $\eta_{e i c}$ is an independently and identically distributed error with a normal distribution and mean zero.

Table 6, column (i), reports the OLS estimate of (4). Labor productivity was positively associated with property rights protection and also the degree of external 
dependence, as measured by the number of suppliers. More importantly, the impact of property rights protection on labor productivity significantly increased with reliance on the external environment. In terms of economic magnitude, the impact of a one standard deviation improvement in property rights protection on labor productivity was 0.080 , or $3.1 \%$ of the mean labor productivity, at the mean number of suppliers. ${ }^{12}$

Our second hypothesis was that the impact of property rights protection on enterprise productivity varied across enterprises facing different levels of entry barriers. According to McMillan and Woodruff (2002), severer expropriation of property rights increases the entry costs, leading to less competition and lower productivity. With the same level of improvement in property rights protection, the percentage of reduction in entry costs is smaller for enterprises with higher levels of entry barriers than for those with lower levels of entry barriers. Thus, it is expected that the enterprises facing lower levels of entry barriers should exhibit relatively higher labor productivity in cities with stronger property rights protection.

Following Djankov, La Porta, Lopez-de-Silanes, and Shleifer (2002), we used the number of days to register a new business to measure, for each enterprise, the level of entry barriers. Accordingly, we estimated the following equation:

$$
y_{e i c}=\mu+\alpha R_{e i c}+\beta E B_{e i c}+\delta R_{e i c} \cdot E B_{e i c}+X_{e i c} \cdot \gamma+\eta_{e i c} \text {, }
$$

where $E B_{\text {eic }}$ measures the level of entry barrier at the enterprise level; $X_{\text {eic }}$ is a vector of controls (CEO and enterprise characteristics, industry dummies, and city dummies); and $\eta_{e i c}$ is an independently and identically distributed error with a normal distribution and mean zero.

Table 6, column (ii), reports the OLS estimate of (5). The impact of property rights protection on labor productivity was larger for enterprises facing lower levels of entry barriers. In terms of economic magnitude, the impact of a one standard deviation

\footnotetext{
${ }^{12}$ In the interaction between property rights protection and the number of suppliers, the number of suppliers was specified as its difference from the sample mean (Wooldridge, 2006b: 204-205). Hence, the coefficient of property rights protection represents the partial effect of property rights protection on labor productivity at the mean number of suppliers.
} 
improvement in property rights protection on labor productivity was 0.034 , or $2.2 \%$ of the mean labor productivity, at the mean level of entry barriers. ${ }^{13}$

Overall, the two-step GMM estimates and the difference-in-differences estimates reinforced the OLS estimates: stronger property rights protection led to higher enterprise productivity. Our result from the enterprise-level analysis is consistent with the general findings in the literature regarding the impacts of institutions on economic growth obtained from the macro-level analysis (e.g., Acemoglu, Johnson, and Robinson, 2001, 2002; Acemoglu and Johnson, 2005). In terms of specific mechanisms through which property rights protection affects enterprise productivity, two channels -- reliance on external environment and entry barriers - appear to be important. Another channel might be the positive impact of property rights protection on investment incentives (e.g., Johnson, McMillan, and Woodruff, 2002; Cull and Xu, 2005) and R\&D investment (Lin, Lin, and Song, 2009), both of which subsequently lead to higher enterprise productivity.

\subsection{Robustness Checks}

We conducted four other sets of robustness checks of the impact of property rights protection on enterprise productivity. First, we re-estimated equation (3) using two alternative measures of enterprise productivity, viz., total factor productivity calculated using either the panel fixed-effects method or the Levinsohn and Petrin (2003) Methodology. Table 7, columns (i)-(ii), reports the results. Clearly, our earlier finding regarding the impact of property rights protection on enterprise productivity was robust to these alternative measures of productivity.

Next, we used an alternative measure of property rights protection, Litigation, measured as the perceived likelihood that the legal system would uphold contract and property rights in business disputes. Table 7, column (iii), reports OLS estimates using this alternative measure of property rights protection. Our earlier finding regarding the

\footnotetext{
${ }^{13}$ In the interaction between property rights protection and the level of entry barriers, the level of entry barriers was specified as its difference from the sample mean (Wooldridge, 2006b: 204205). Hence, the coefficient of property rights protection represents the partial effect of property rights protection on labor productivity at the mean level of entry barriers.
} 
impact of property rights protection on enterprise productivity was robust to this alternative measure of property rights. ${ }^{14}$

Another concern might be that our results were driven by particular outliers. To address this issue, we used the quantile regression to estimate specification (3). Table 7, column (iv), reports the results. Our earlier finding regarding the impact of property rights protection on labor productivity was robust to outliers.

Finally, yet another concern might be that our results could be biased due to the inclusion of state-owned enterprises. This is because state-owned enterprises conduct business under the auspices of national and regional governments (thus enjoying better de facto property rights protection), and they have lower productivity due to the multiple responsibilities that they are charged with (Bai, Li, Tao, and Wang, 2000). To rule out this concern, we restricted our sample to private enterprises, which were defined as those enterprises with more than $50 \%$ percentage of private ownership. Table 7 , column (v), reports the results. Clearly, our earlier finding regarding the impact of property rights protection on labor productivity was robust to this subsample. In terms of economic magnitude, the impact of a one standard deviation improvement in property rights protection on labor productivity was 0.097 , or $6.2 \%$ of the mean labor productivity. Consistent with intuition, this value was significantly higher than that obtained from the whole sample (see Table 3, column (vi)).

\section{Conclusion}

It is widely believed that China's spectacular growth in the last thirty years contradicts the prevailing view of the importance of institutions to economic performance (Blanchard and Kremer 1997; Rodrik 2004a and 2004b; Allen, Qian, and Qian 2005; Economist, March 15, 2008). Indeed, protection of private property was not formally written into China's constitution until 2004, and its legal institutions were rather weak.

Using data from a World Bank survey of 1,566 manufacturing enterprises in 18 Chinese cities, we found that property rights protection had a positive and statistically

${ }^{14}$ In unreported estimates, we found that Litigation was statistically insignificant with the inclusion of Property Rights Protection (which was measured by the effectiveness of seeking help from the government officials).. This finding suggested that indeed, the protection of private property hinged upon the state, which is consistent with the previous literature and observations in China. 
significant impact on enterprise productivity. These results were robust to the inclusion of a comprehensive list of controls related to CEO and enterprise characteristics, as well as industry and city dummies.

To further establish the causal impacts of property rights protection on enterprise productivity, we applied two-step GMM estimation with two alternative instruments, viz, the average perception of property rights protection among other enterprises belonging to other industries located in the same city, and the logarithm of population in the respective city around 1918-19. The two-step GMM estimates reinforced our findings that property rights protection had a positive and significant causal impact on productivity.

In addition, we applied difference-in-differences estimation (Rajan and Zingales, 1998) to further establish causality by focusing on the theoretical mechanisms through which property rights protection might affect enterprise performance. We found that enterprises which were more reliant on the external environment exhibited relatively higher productivity in cities with stronger property rights protection. We also found that enterprises which faced lower levels of entry barriers exhibited relatively higher productivity in cities with stronger property rights protection.

In further robustness checks, we explored alternative measures of productivity and property rights protection, used the quantile regression to deal with possible impact of outlying observations, and investigated whether the results were biased due to the inclusion of state-owned enterprises.

Finally, we did find evidence that property rights protection was, to some extent, correlated with geography. This would be consistent with the explanation of China's growth as being concentrated in the coastal areas, where institutional quality is relatively higher. 


\section{References}

Acemoglu, Daron and Simon Johnson (2005) "Unbundling Institutions", Journal of Political Economy 113, 949-995.

Acemoglu, Daron, Simon Johnson, and James A. Robinson (2001) "The Colonial Origins of Comparative Development: An Empirical Investigation", American Economic Review 91, 1369-1401.

Acemoglu, Daron, Simon Johnson, and James A. Robinson (2002) "Reversal of Fortune: Geography and Institutions in the Making of the Modern World Income Distribution", Quarterly Journal of Economics 117, 1231-1294.

Acemoglu, Daron and Fabrizio Zilibotti (2001) "Productivity Differences", Quarterly Journal of Economics 116, 563-606.

Allen, Franklin, Jun Qian, and Meijun Qian (2005) "Law, Finance, and Economic Growth in China," Journal of Financial Economics 77, 57-116.

Angrist, Joshua and Jörn-Steffen Pischke (2009) Mostly Harmless Econometrics, Princeton University Press.

Asian Development Bank (2003) "The Development of Private Enterprises in the People's Republic of China", March.

Ayyagari Meghana, Alis Demirgüç-Kunt, and Vojislav Maksimovic (2007) "Formal versus Informal Finance: Evidence from China," working paper.

Bai, Chong-en, Yingjuan Du, Zhigang Tao, Sarah Y. Tong (2004) “Local protectionism and regional specialization: evidence from China's industries", Journal of International Economics 63, 397-417.

Bai, Chong-en, David D. Li, Zhigang Tao, and Yijiang Wang (2000) “A Multi-Task Theory of the State Enterprise Reform”, Journal of Comparative Economics 28, 716-738.

Barro, Robert (2001) "Human Capital and Growth”, American Economic Review 91, 1217.

Berry, Steven, James Levinsohn, and Ariel Pakes (1995) “Automobile Prices in Market Equilibrium”, Econometrica 60, 889-917.

Bisin, Alberto and Thierry Verdier (2000) "Beyond the Melting Pot: Cultural Transmission, Marriage, and the Evolution of Ethnic and Religious Traits", Quarterly Journal of Economics 115, 955-988.

Besley, Timothy (1995) "Property Rights and Investment Incentives: Theory and Evidence from Ghana", Journal of Political Economy 103, 903-937.

Besley, Timothy and Maitreesh Ghatak (2009) "Property Rights and Economic Development", in Dani Rodrik and Mark R. Rosenzweig eds. Handbook of Development Economics Volumn 5, North-Holland. 
Blanchard, Olivier and Michael Kremer (1997) "Disorganization," Quarterly Journal of Economics 112, 1091-1126.

Carothers, Thomas (2006) Promoting the Rule of Law Abroad: In Search of Knowledge, Washington, DC: Carnegie Endowment for International Peace.

Chen, Ta (1947) “An Appraisal of China's Historical Population Data”, American Journal of Sociology 52, Supplement: Population in Modern China, 1-6.

Clarke, Donald (1991) "Dispute Resolution in China", Journal of Chinese Law 5, 244296.

Cull, Robert and Lixin Colin Xu (2005) "Institutions, Ownership, and Finance: the Determinant of Profit Reinvestment among Chinese Firms", Journal of Financial Economics 77, 117-146.

De Loecker, Jan (2009) "Product Differentiation, Multi-Product Firms and Estimating the Impact of Trade Liberalization on Productivity”, working paper.

Djankov, Simeon, Rafael La Porta, Florencio Lopez-de-Silanes, and Andrei Shleifer (2002) "The Regulation of Entry", Quarterly Journal of Economics 117, 1-37.

Dohmen, Thomas, Armin Falk, David Huaman, and Uwe Sunde (2006) "The Intergenerational Transmission of Risk and Trust Attitudes", IZA DP 2380.

Dong, Shouyi, Lizhen Zhang, and Runmin Jiao (2000) Lectures on Modern History of China Volume I. Beijing, China: Chinese Social Science Press.

Dong, Xiao-yuan and Lixin Colin Xu (2009) "Labor Restructuring in China: Toward a Functioning Labor Market”, Journal of Comparative Economics, 37, 287-305.

Du, Julan, Yi Lu, and Zhigang Tao (2008) "Economic Institutions and FDI Location Choice: Evidence from US Manufacturing Firms in China", Journal of Comparative Economics 36, 412-429.

Du, Julan and Chenggang Xu (2009) "Which Firms Went Public in China? A Study of Financial Market Regulation", World Development, forthcoming.

Economist (2008) “Economics and the Rule of Law”, March 15, 2008, 83-85.

Fan, Chengzhi (1985) "The Position of the People's Courts in the Structure of the State", Jurisprudence Magazine (Faxue Zazhi in Chinese) 4.

Fan, Wenlan (1955) Modern History of China. Beijing, China: People's Press.

Fang, Ying, and Zhao, Yang (2007) "Do Institutions Matter? Estimating the Effects of Institutions on Economic Performance in China”, working paper, http://ssrn.com/abstract=957719.

Fu, Yunsheng (2003) "Business Culture Tradition and Regional Economic Development Analysis", Economist (Jing Ji Xue Jia, a Chinese journal), No. 5. 
Hall, Robert E. and Charles I. Jones (1999) "Why Do Some Countries Produce So Much More Output per Worker than Others?" Quarterly Journal of Economics 114, 83-116.

Ho, Ping-ti (1959) Studies on the Population of China, 1368-1953, Cambridge, MA: Harvard University Press.

Johnson, Simon, John McMillan, and Christopher Woodruff (2002) "Property Rights and Finance", American Economic Review 22, 1335-1356.

Klette, Tor Jakob and Zvi Griliches (1996) “The Inconsistency of Common Scale Estimators when Output Prices are Unobserved and Endogenous”, Journal of Applied Econometrics 11, 343-361.

Knack, Stephen and Philip Keefer (1995) "Institutions and Economic Performance: Cross-Country Tests Using Alternative Institutional Measures", Economics and Politics 7, 207-227.

Knack, Stephen and Philip Keefer (1997) "Does Social Capital Have an Economic Payoff? A Cross-Country Investigation", Quarterly Journal of Economics 112, 1251-1288.

La Porta, Rafael, Florencio Lopez-de-Silanes, and Andrei Shleifer (2008) "The Economics Consequences of Legal Origin", Journal of Economic Perspectives 46, 285332.

La Porta, Rafael, Florencio Lopez-de-Silanes, Andrei Shleifer, and Robert Vishny (1997) "Legal Determinants of External Finance", Journal of Finance 52, 1131-1150.

La Porta, Rafael, Florencio Lopez-de-Silanes, Andrei Shleifer, and Robert Vishny (1998) "Law and Finance", Journal of Political Economy 106, 1113-1155.

La Porta, Rafael, Florencio Lopez-de-Silanes, Andrei Shleifer, and Robert Vishny (1999) "The Quality of Government", Journal of Law, Economics and Organization 15, 222-279.

Levinsohn, James and Amil Petrin (2003) "Estimating Production Functions Using Inputs to Control for Unobservables", Review of Economic Studies 70, 317-342.

Li, Ben and Yi Lu (2009) "Geographic Concentration and Vertical Disintegration: Evidence from China", Journal of Urban Economics 65, 294-304.

Li, Hongbin, Lingsheng Meng, Qian Wang, and Li-an Zhou (2008) “Political Connections, Financing and Firm Performance: Evidence from Chinese Private Entrepreneurs”, Journal of Development Economics 87, 283-299.

Li, Kan, Shiyue Li, Dezheng Li, Ce Yang, and Shuduo Gong (1994) Modern History of China, Beijing, China: Zhonghua Book Company.

Li,Wensen, Bingde Zhang, and Fengzhu Wang (1990) "A Brief Discussion of the Reasons for the Antagonistic Attitude of a Party Before Execution and Measures for Preventing It", People's Judicature (Renmin Sifa in Chinese) 5. 
Liang, Kung-Yee and Scott L. Zeger (1986) "Longitudinal Data Analysis Using Generalized Linear Models", Biometrika 73, 13-22.

Lieberthal, Kenneth and Michael Oksenberg (1988) Policy Making in China: Leaders, Structures, and Processes, Princeton: Princeton University Press.

Lin, Ping, Chen Lin, and Frank Song (2009) "Property Rights Protection and Corporate R\&D: Evidence from China", Journal of Development Economics, Forthcoming."

Lu, Jiangyong and Zhigang Tao (2009b) "Trends and Determinants of China's Industrial Agglomeration", Journal of Urban Economics 65, 167-180.

Lu, Yi and Zhigang Tao (2009a) "Contract Enforcement and Family Control of Business: Evidence from China", Journal of Comparative Economics, forthcoming.

Mauro, Paolo (1995) "Corruption and Growth", Quarterly Journal of Economics 110, 681-712.

McMillan, John and Christopher Woodruff (2002) "The Central Role of Entrepreneurs in Transition Economies”, Journal of Economic Perspectives 16, 153-170.

Nevo, Aviv (2000) "Mergers with Differentiated Products: The Case of the Ready-to-Eat Cereal Industry”, RAND Journal of Economics 31, 395-421.

Nevo, Aviv (2001) "Measuring Market Power in the Ready-to-Eat Cereal Industry", Econometrica 69, 307-342.

Ni, Pengfei, et al. (2004 and 2005) Zhong Guo Cheng Shi Jing Zheng Li Bao Gao (Annual Report on Urban Competitiveness) Beijing, China: Social Sciences Academic Press.

North, Douglass C. (1991) "Institutions", Journal of Economic Perspectives 5, 97-112.

Pistor, Katharina and Chenggang Xu (2002) "Incomplete Law ---- A Conceptual and Analytical Framework ---- And its Application to the Evolution of Financial Market Regulation", working Paper No. 204, The Center for Law and Economic Studies, Columbia Law School.

Rajan, Raghuram G. and Arvind Subramanian (2007) "Does Aid Affect Governance?" American Economic Review Papers and Proceedings 97, 322-326.

Rajan, Raghuram G. and Luigi Zingales (1998) "Financial Dependence and Growth", American Economic Review 3, 559-586.

Rawski, Thomas G. (1989) Economic Growth in Prewar China, Berkeley, CA: University of California Press.

Rodrik, Dani (2004a) "Rethinking Economic Growth in Developing Countries", The Luca d'Agliano Lecture.

Rodrik, Dani (2004b) “Getting Institutions Right”, DICE Report 2/2004, CESifo, 10-15. 
Special Committee on Survey and Occupation of China Continuation Committee (1987) Statistics of China Christianism (Revised Edition by Chinese Academy of Social Sciences): 1901-1920. Beijing: Chinese Academy of Social Sciences Press.

Staiger, Douglas and James Stock (1997) "Instrumental Variables Regression with Weak Instruments", Econometrica 65, 557-586.

Tabellini, Guido (2007a) "Culture and Institutions: Economic Development in the Regions of Europe", working paper.

Tabellini, Guido (2007b) "Institutions and Culture", working paper.

Tabellini, Guido (2009) "The Scope of Cooperation: Values and Incentives", Quarterly Journal of Economics, forthcoming.

Wang, Ke (2006) "China Faced with Skilled Labor Shortage", China.org.cn, http://www.china.org.cn/english/MATERIAL/172145.htm (accessed on August 24, 2009).

Wooldridge, Jeffrey M. (2003) "Cluster-Sample Methods in Applied Econometrics", American Economic Review 93, 133-138.

Wooldridge, Jeffrey M. (2006a) "Cluster Sample Methods in Applied Econometrics: An Extended Analysis", working paper.

Wooldridge, Jeffrey M. (2006b) Introductory Econometrics: A Modern Approach, Third Edition, Mason, $\mathrm{OH}$ : Thomson.

World Bank (2008) Doing Business in China 2008, Beijing, China: Social Science Academic Press.

Wu, Jiang (1955) "Some Characteristics of China's Capitalist Economic Development", Jingji Yanjiu (Journal of Economic Research, in Chinese), 5.

Young, Alwyn (2000) “The razor’s edge: distortions and incremental reform in the People’s Republic of China”, Quarterly Journal of Economics 115, 1091- 1135.

Young, Crawford (1994) The African Colonial State in Comparative Perspective, New Haven, CT: Yale University Press.

Zhao, Yongchen (1989) "A Provision Should Be Added to the Criminal Law Criminalizing Contempt of Court", Modern Jurisprudence (Xiandai Faxue in Chinese) 1.

Zhu, Ying (2001) Merchants and Society in Modern China, Hubei, China: Hubei Education Press. 
Table 1. Summary Statistics

\begin{tabular}{l|ccccc}
\hline \multicolumn{1}{c|}{ Variable } & Obs & Mean & Std. Dev. & Min & Max \\
\hline Labor productivity & 1557 & 4.322 & 1.562 & -3.989 & 11.893 \\
Total factor productivity (fixed effect) & 1356 & 4.151 & 1.077 & -0.983 & 11.069 \\
Total factor productivity (LP) & 1356 & 3.042 & 0.953 & -2.363 & 10.123 \\
Property rights protection & 1462 & 0.355 & 0.320 & 0.000 & 1.000 \\
Court litigation & 1361 & 0.634 & 0.389 & 0.000 & $1.000 \mathrm{C}$ \\
Average perceived property rights & & & & & \\
protection among other industries in same & 1566 & 0.349 & 0.106 & 0.175 & 0.623 \\
city & & & & & \\
Logarithm of population in 1918-19 & 1437 & 11.926 & 0.836 & 10.463 & 13.385 \\
Enterprise size & 1563 & 5.040 & 1.454 & 0.000 & 9.899 \\
Enterprise age & 1566 & 2.494 & 0.777 & 1.099 & 3.970 \\
Private ownership percentage & 1566 & 0.813 & 0.376 & 0.000 & 1.000 \\
Skilled labor ratio & 1542 & 0.026 & 0.060 & 0.000 & 1.000 \\
CEO education & 1553 & 15.359 & 2.511 & 0.000 & 19.000 \\
CEO tenure & 1548 & 6.240 & 4.580 & 1.000 & 33.000 \\
Deputy CEO previously & 1548 & 0.280 & 0.449 & 0.000 & 1.000 \\
Government cadre previously & 1548 & 0.036 & 0.185 & 0.000 & 1.000 \\
Party member & 1524 & 0.648 & 0.478 & 0.000 & 1.000 \\
Government appointed CEO & 1544 & 0.243 & 0.429 & 0.000 & 1.000 \\
Number of suppliers (in thousands) & 1509 & 0.042 & 0.199 & 0.000 & 7.100 \\
Entry barriers & 778 & 8.817 & 11.811 & 0.000 & 100.000 \\
Property rights protection x suppliers ${ }^{1}$ & 1423 & 0.000 & 0.044 & -0.041 & 0.825 \\
Property rights protection x entry barriers $^{2}$ & 733 & -0.380 & 4.284 & -8.817 & 28.414 \\
\hline Notes:
\end{tabular}

Notes:

1. Number of suppliers was specified as its difference from the sample mean.

2. Entry barriers were specified as their difference from the sample mean. 
Table 2. Correlations

\begin{tabular}{|c|c|c|c|c|c|c|c|}
\hline & $\begin{array}{l}\text { Labor } \\
\text { productivity }\end{array}$ & $\begin{array}{c}\text { Total factor } \\
\text { productivity } \\
\text { (fixed } \\
\text { effect) } \\
\end{array}$ & $\begin{array}{l}\text { Total factor } \\
\text { productivity } \\
\text { (LP) }\end{array}$ & $\begin{array}{l}\text { Property } \\
\text { rights } \\
\text { protection }\end{array}$ & Court litigation & $\begin{array}{l}\text { Average } \\
\text { perceived } \\
\text { property } \\
\text { rights } \\
\text { protection } \\
\text { among other } \\
\text { industries in } \\
\text { same city } \\
\end{array}$ & $\begin{array}{l}\text { Logarithm of } \\
\text { population in } \\
\text { 1918-19 }\end{array}$ \\
\hline Labor productivity & 1.000 & & & & & & \\
\hline Total factor productivity (fixed effect) & 0.821 & 1.000 & & & & & \\
\hline Total factor productivity (LP) & 0.820 & 0.968 & 1.000 & & & & \\
\hline Property rights protection & 0.109 & 0.097 & 0.082 & 1.000 & & & \\
\hline Court litigation & 0.095 & 0.074 & 0.053 & 0.258 & 1.000 & & \\
\hline $\begin{array}{l}\text { Average perceived property rights } \\
\text { protection among other industries in } \\
\text { same city }\end{array}$ & 0.113 & 0.116 & 0.088 & 0.257 & 0.155 & 1.000 & \\
\hline Logarithm of population in 1918-19 & 0.132 & 0.157 & 0.125 & 0.090 & 0.064 & 0.299 & 1.000 \\
\hline
\end{tabular}


Table 3. OLS estimates

\begin{tabular}{|c|c|c|c|c|c|c|}
\hline \multirow[b]{2}{*}{ Dependent variable } & (i) & (ii) & (iii) & (iv) & (v) & (vi) \\
\hline & \multicolumn{6}{|c|}{ Labor productivity } \\
\hline Property rights protection & $\begin{array}{l}0.511^{\star \star \star} \\
{[0.142]}\end{array}$ & $\begin{array}{l}0.448^{\star \star \star} \\
{[0.142]}\end{array}$ & $\begin{array}{c}0.426^{\star \star *} \\
{[0.138]}\end{array}$ & $\begin{array}{l}0.321^{\star *} \\
{[0.130]}\end{array}$ & $\begin{array}{l}0.309^{* \star} \\
{[0.118]}\end{array}$ & $\begin{array}{l}0.245^{\star \star} \\
{[0.104]}\end{array}$ \\
\hline \multicolumn{7}{|l|}{ CEO characteristics } \\
\hline \multicolumn{7}{|l|}{ Human capital } \\
\hline CEO education & & $\begin{array}{l}0.152^{\star \star \star} \\
{[0.019]}\end{array}$ & $\begin{array}{l}0.154^{\star \star \star} \\
{[0.019]}\end{array}$ & $\begin{array}{l}0.101^{\star * *} \\
{[0.020]}\end{array}$ & $\begin{array}{c}0.077^{\star * *} \\
{[0.021]}\end{array}$ & $\begin{array}{c}0.068^{\star * *} \\
{[0.020]}\end{array}$ \\
\hline CEO tenure & & $\begin{array}{l}-0.020^{\star *} \\
{[0.009]}\end{array}$ & $\begin{array}{l}-0.009 \\
{[0.010]}\end{array}$ & $\begin{array}{c}0.008 \\
{[0.009]}\end{array}$ & $\begin{array}{l}0.016^{*} \\
{[0.008]}\end{array}$ & $\begin{array}{c}0.001 \\
{[0.008]}\end{array}$ \\
\hline Deputy CEO previously & & $\begin{array}{l}-0.183^{\star \star} \\
{[0.078]}\end{array}$ & $\begin{array}{c}-0.022 \\
{[0.082]}\end{array}$ & $\begin{array}{c}0.075 \\
{[0.077]}\end{array}$ & $\begin{array}{c}0.038 \\
{[0.077]}\end{array}$ & $\begin{array}{c}0.026 \\
{[0.071]}\end{array}$ \\
\hline \multicolumn{7}{|l|}{ Political capital } \\
\hline Government cadre previously & & & $\begin{array}{c}0.036 \\
{[0.213]}\end{array}$ & $\begin{array}{c}0.044 \\
{[0.188]}\end{array}$ & $\begin{array}{c}0.075 \\
{[0.170]}\end{array}$ & $\begin{array}{c}0.133 \\
{[0.176]}\end{array}$ \\
\hline Party member & & & $\begin{array}{l}-0.250^{\star * *} \\
{[0.093]}\end{array}$ & $\begin{array}{l}-0.175^{\star \star} \\
{[0.087]}\end{array}$ & $\begin{array}{l}-0.177^{\star \star} \\
{[0.078]}\end{array}$ & $\begin{array}{c}-0.051 \\
{[0.073]}\end{array}$ \\
\hline CEO government appointed & & & $\begin{array}{l}-0.635^{\star \star \star} \\
{[0.099]}\end{array}$ & $\begin{array}{l}-0.308^{\star \star \star} \\
{[0.110]}\end{array}$ & $\begin{array}{c}-0.309^{\star \star \star} \\
{[0.104]}\end{array}$ & $\begin{array}{c}-0.260^{* *} \\
{[0.111]}\end{array}$ \\
\hline \multicolumn{7}{|l|}{ Enterprise characteristics } \\
\hline Enterprise size & & & & $\begin{array}{l}0.249 * \star * \\
{[0.039]}\end{array}$ & $\begin{array}{l}0.237^{\star * *} \\
{[0.040]}\end{array}$ & $\begin{array}{c}0.139^{* * *} \\
{[0.038]}\end{array}$ \\
\hline Enterprise age & & & & $\begin{array}{l}-0.555^{\star * *} \\
{[0.071]}\end{array}$ & $\begin{array}{c}-0.528^{* \star *} \\
{[0.069]}\end{array}$ & $\begin{array}{l}-0.455^{\star * *} \\
{[0.065]}\end{array}$ \\
\hline Private ownership percentage & & & & $\begin{array}{c}0.146 \\
{[0.139]}\end{array}$ & $\begin{array}{c}0.156 \\
{[0.141]}\end{array}$ & $\begin{array}{c}0.170 \\
{[0.137]}\end{array}$ \\
\hline Skilled labor ratio & & & & $\begin{array}{c}2.756^{\star \star \star} \\
{[0.751]}\end{array}$ & $\begin{array}{l}2.110^{* *} \\
{[0.853]}\end{array}$ & $\begin{array}{c}2.023^{\star * \star} \\
{[0.763]}\end{array}$ \\
\hline $\begin{array}{l}\text { Industry characteristics } \\
\text { Industry dummies } \\
\text { City characteristics }\end{array}$ & & & & & Yes & Yes \\
\hline City dummies & & & & & & Yes \\
\hline Constant & $\begin{array}{c}4.139 * \star \star \\
{[0.110]}\end{array}$ & $\begin{array}{c}2.004^{\star \star \star} \\
{[0.333]}\end{array}$ & $\begin{array}{c}2.172^{\star \star \star} \\
{[0.324]}\end{array}$ & $\begin{array}{c}2.695^{\star \star \star} \\
{[0.386]}\end{array}$ & $\begin{array}{c}2.968^{\star \star \star} \\
{[0.459]}\end{array}$ & $\begin{array}{c}2.621^{\star \star \star} \\
{[0.527]}\end{array}$ \\
\hline No. of observations & 1453 & 1424 & 1385 & 1369 & 1369 & 1369 \\
\hline $\mathrm{R}^{2}$ & 0.0111 & 0.0828 & 0.1221 & 0.2106 & 0.2587 & 0.334 \\
\hline $\begin{array}{l}p \text {-value for F-test } \\
\text { Impact of property rights }\end{array}$ & 0.0000 & 0.0000 & 0.0000 & 0.0000 & 0.0000 & 0.0000 \\
\hline protection $^{2}$ & 0.164 & 0.143 & 0.136 & 0.103 & 0.099 & 0.078 \\
\hline
\end{tabular}

Notes:

1. Standard errors, clustered at the industry-city level, are reported in the bracket; *, $* *$, *** represent significance at $10 \%, 5 \%$, and $1 \%$, respectively.

2. Impact as measured by a one standard deviation increase in Property Rights Protection. 
Table 4. GMM estimates: Property rights protection as perceived by others

\begin{tabular}{|c|c|c|c|c|}
\hline \multirow{2}{*}{$\begin{array}{l}\text { Estimation specification } \\
\text { Dependent variable }\end{array}$} & (i) $\mathrm{GN}$ & (ii) & \multicolumn{2}{|c|}{ (iii) OLS $^{\text {(iv) }}$} \\
\hline & $\begin{array}{l}\text { First stage } \\
\text { Property rights } \\
\text { protection }\end{array}$ & $\begin{array}{l}\text { Second stage } \\
\text { Labor } \\
\text { productivity }\end{array}$ & \multicolumn{2}{|c|}{ Labor productivity } \\
\hline Property rights protection & & $\begin{array}{l}1.331^{*} \\
{[0.766]}\end{array}$ & & $\begin{array}{l}0.201^{*} \\
{[0.108]}\end{array}$ \\
\hline $\begin{array}{l}\text { Average perceived property rights } \\
\text { protection among other industries in } \\
\text { same city }\end{array}$ & $-3.063^{\star \star \star}$ & & $-4.077^{\star}$ & -3.462 \\
\hline $\begin{array}{l}\text { CEO characteristics } \\
\text { Human capital }\end{array}$ & {$[0.239]$} & & [2.386] & [2.468] \\
\hline CEO education & $\begin{array}{c}0.004 \\
{[0.004]}\end{array}$ & $\begin{array}{c}0.063^{\star * \star} \\
{[0.021]}\end{array}$ & $\begin{array}{c}0.068^{\star \star *} \\
{[0.020]}\end{array}$ & $\begin{array}{c}0.067^{\star \star *} \\
{[0.020]}\end{array}$ \\
\hline CEO tenure & $\begin{array}{c}0.000 \\
{[0.002]}\end{array}$ & $\begin{array}{c}0.000 \\
{[0.008]}\end{array}$ & $\begin{array}{c}0.001 \\
{[0.008]}\end{array}$ & $\begin{array}{c}0.001 \\
{[0.008]}\end{array}$ \\
\hline Deputy CEO previously & $\begin{array}{l}-0.022 \\
{[0.016]}\end{array}$ & $\begin{array}{c}0.046 \\
{[0.069]}\end{array}$ & $\begin{array}{c}0.017 \\
{[0.072]}\end{array}$ & $\begin{array}{c}0.021 \\
{[0.072]}\end{array}$ \\
\hline Political capital & & & & \\
\hline Government cadre previously & $\begin{array}{l}-0.065 \\
{[0.055]}\end{array}$ & $\begin{array}{c}0.189 \\
{[0.182]}\end{array}$ & $\begin{array}{c}0.103 \\
{[0.178]}\end{array}$ & $\begin{array}{c}0.116 \\
{[0.177]}\end{array}$ \\
\hline Party member & $\begin{array}{l}-0.018 \\
{[0.019]}\end{array}$ & $\begin{array}{l}-0.032 \\
{[0.070]}\end{array}$ & $\begin{array}{l}-0.055 \\
{[0.073]}\end{array}$ & $\begin{array}{c}-0.052 \\
{[0.073]}\end{array}$ \\
\hline Government appointed CEO & $\begin{array}{c}0.006 \\
{[0.022]}\end{array}$ & $\begin{array}{l}-0.253^{\star \star} \\
{[0.103]}\end{array}$ & $\begin{array}{l}-0.245^{\star *} \\
{[0.113]}\end{array}$ & $\begin{array}{c}-0.246^{\star \star} \\
{[0.112]}\end{array}$ \\
\hline Enterprise characteristics & & & & \\
\hline Enterprise size & $\begin{array}{c}0.012 \\
{[0.008]}\end{array}$ & $\begin{array}{l}0.128^{* * \star} \\
{[0.041]}\end{array}$ & $\begin{array}{c}0.144^{\star \star *} \\
{[0.038]}\end{array}$ & $\begin{array}{c}0.141^{\star * \star} \\
{[0.038]}\end{array}$ \\
\hline Enterprise age & $\begin{array}{l}-0.008 \\
{[0.013]}\end{array}$ & $\begin{array}{c}-0.444^{\star \star \star} \\
{[0.064]}\end{array}$ & $\begin{array}{c}-0.455^{\star * *} \\
{[0.067]}\end{array}$ & $\begin{array}{c}-0.454^{\star * *} \\
{[0.066]}\end{array}$ \\
\hline Private ownership percentage & $\begin{array}{c}0.007 \\
{[0.033]}\end{array}$ & $\begin{array}{c}0.175 \\
{[0.127]}\end{array}$ & $\begin{array}{c}0.185 \\
{[0.138]}\end{array}$ & $\begin{array}{c}0.183 \\
{[0.136]}\end{array}$ \\
\hline Skilled labor ratio & $\begin{array}{c}0.023 \\
{[0.148]}\end{array}$ & $\begin{array}{c}1.947^{\star \star \star} \\
{[0.697]}\end{array}$ & $\begin{array}{l}1.977^{* *} \\
{[0.781]}\end{array}$ & $\begin{array}{l}1.973^{* *} \\
{[0.767]}\end{array}$ \\
\hline Industry characteristics & & & & \\
\hline $\begin{array}{l}\text { Industry dummies } \\
\text { City characteristics }\end{array}$ & Yes & Yes & Yes & Yes \\
\hline City dummies & Yes & Yes & Yes & Yes \\
\hline Constant & $\begin{array}{l}1.493^{\star \star *} \\
{[0.107]}\end{array}$ & $\begin{array}{c}3.190 * * * \\
{[0.508]}\end{array}$ & $\begin{array}{l}6.472^{\star * \star} \\
{[1.048]}\end{array}$ & $\begin{array}{c}3.779 * * * \\
{[0.975]}\end{array}$ \\
\hline Tests & & & & \\
\hline $\begin{array}{l}\text { Relevance tests } \\
\text { Anderson canonical correlations LR } \\
\text { statistic }\end{array}$ & {$[44.08]^{\star \star *}$} & - & - & - \\
\hline $\begin{array}{l}\text { Cragg-Donald Wald statistic } \\
\text { Weak instrument tests } \\
\text { Shea partial } \mathrm{R}^{2}\end{array}$ & {$[55.30]^{\star \star \star}$} & - & - & - \\
\hline
\end{tabular}




\begin{tabular}{l|cc|cc} 
Cragg-Donald F-statistic & {$[53.29]$} & - & - & - \\
\hline No. of observations & 1369 & 1369 & 1369 & 1369 \\
Impact of property rights protection $^{2}$ & - & 0.426 & - & - \\
\hline
\end{tabular}

Notes:

1. Standard errors, clustered at the industry-city level, are reported in the bracket; *, **, *** represent significance at $10 \%, 5 \%$, and $1 \%$, respectively.

2. Impact as measured by a one standard deviation increase in Property Rights Protection. 
Table 5. GMM estimates: Historical population

\begin{tabular}{|c|c|c|c|c|}
\hline & (i) & (ii) & (iii) & (iv) \\
\hline \multicolumn{5}{|c|}{ Second Stage: Dependent Variable: Labor productivity } \\
\hline Property rights protection & $\begin{array}{l}4.787^{* \star *} \\
{[1.487]}\end{array}$ & $\begin{array}{c}4.193^{\star \star *} \\
{[1.265]}\end{array}$ & $\begin{array}{l}4.105^{\star \star \star} \\
{[1.407]}\end{array}$ & $\begin{array}{l}3.590 * \star \star \\
{[1.107]}\end{array}$ \\
\hline Losses due to theft & & $\begin{array}{l}19.958 \\
{[16.591]}\end{array}$ & $\begin{array}{c}20.284 \\
{[16.982]}\end{array}$ & $\begin{array}{c}21.856 \\
{[16.103]}\end{array}$ \\
\hline Clustering of suppliers & & & $\begin{array}{l}-0.509 \\
{[1.265]}\end{array}$ & $\begin{array}{l}-0.804 \\
{[1.164]}\end{array}$ \\
\hline Local protectionism & & & & $\begin{array}{c}0.820 \\
{[0.674]}\end{array}$ \\
\hline Controls & & & & \\
\hline Enterprise characteristics & Yes & Yes & Yes & Yes \\
\hline CEO characteristics & Yes & Yes & Yes & Yes \\
\hline Industry dummies & Yes & Yes & Yes & Yes \\
\hline Logarithm of GDP per capita & Yes & Yes & Yes & Yes \\
\hline Impact of property rights protection ${ }^{2}$ & 1.532 & 1.342 & 1.314 & 1.149 \\
\hline \multicolumn{5}{|c|}{ First Stage: Dependent Variable: Property rights protection } \\
\hline Logarithm of population in 1918-19 & $\begin{array}{c}0.044^{\star \star \star} \\
{[0.015]}\end{array}$ & $\begin{array}{c}0.050 \star \star \star \\
{[0.015]}\end{array}$ & $\begin{array}{c}0.046^{\star \star \star} \\
{[0.014]}\end{array}$ & $\begin{array}{c}0.063^{\star \star \star} \\
{[0.012]}\end{array}$ \\
\hline Losses due to theft & & $\begin{array}{l}-4.304 \\
{[3.287]}\end{array}$ & $\begin{array}{l}-3.840 \\
{[3.229]}\end{array}$ & $\begin{array}{l}-6.263^{\star} \\
{[3.268]}\end{array}$ \\
\hline Clustering of suppliers & & & $\begin{array}{l}-0.388^{\star \star} \\
{[0.161]}\end{array}$ & $\begin{array}{l}-0.322^{*} \\
{[0.172]}\end{array}$ \\
\hline Local protectionism & & & & $\begin{array}{l}-0.560^{\star \star \star} \\
{[0.155]}\end{array}$ \\
\hline Controls & & & & \\
\hline Enterprise characteristics & Yes & Yes & Yes & Yes \\
\hline CEO characteristics & Yes & Yes & Yes & Yes \\
\hline Industry dummies & Yes & Yes & Yes & Yes \\
\hline $\begin{array}{l}\text { Logarithm of GDP per capita } \\
\text { Tests }\end{array}$ & Yes & Yes & Yes & Yes \\
\hline Relevance tests & & & & \\
\hline Anderson canonical correlations LR statistic & {$[14.61]^{\star \star \star}$} & {$[18.52]^{\star \star \star}$} & {$[15.85]^{\star \star *}$} & {$[24.78]^{\star \star \star}$} \\
\hline $\begin{array}{l}\text { Cragg-Donald Wald statistic } \\
\text { Weak instrument tests }\end{array}$ & {$[14.87]^{\star \star \star}$} & {$[19.10]^{\star \star \star}$} & {$[16.29]^{\star \star \star}$} & {$[27.49]^{\star \star *}$} \\
\hline Shea partial $R^{2}$ & 0.0114 & 0.0148 & 0.0127 & 0.0215 \\
\hline Cragg-Donald F-statistic & [14.46] & [18.56] & [15.81] & {$[26.67]$} \\
\hline No. of observations & 1268 & 1247 & 1234 & 1234 \\
\hline
\end{tabular}

Notes:

1. Standard errors, clustered at the industry-city level, are reported in the bracket; *, **, *** represent significance at $10 \%, 5 \%$, and $1 \%$, respectively.

2. Impact as measured by a one standard deviation increase in Property Rights Protection. 
Table 6. Difference-in-differences estimates

\begin{tabular}{|c|c|c|}
\hline Dependent variable & $\begin{array}{c}\text { (i) } \\
\text { Labor } p\end{array}$ & $\begin{array}{c}\text { (ii) } \\
\text { Ictivity }\end{array}$ \\
\hline Property rights protection & $\begin{array}{l}0.253^{\star \star} \\
{[0.105]}\end{array}$ & $\begin{array}{c}0.106 \\
{[0.158]}\end{array}$ \\
\hline Number of suppliers (in thousands) & $\begin{array}{c}0.094 \\
{[0.141]}\end{array}$ & \\
\hline Property rights protection $\times$ Supplier $^{2}$ & $\begin{array}{c}3.476^{\star \star \star} \\
{[0.845]}\end{array}$ & \\
\hline Entry barriers & & $\begin{array}{c}0.006 \\
{[0.006]}\end{array}$ \\
\hline Property rights protection $\times$ Entry barriers ${ }^{3}$ & & $\begin{array}{l}-0.036^{*} \\
{[0.018]}\end{array}$ \\
\hline Controls & & \\
\hline Industry dummies & Yes & Yes \\
\hline City dummies & Yes & Yes \\
\hline Enterprise characteristics & Yes & Yes \\
\hline CEO characteristics & Yes & Yes \\
\hline No. of observations & 1337 & 689 \\
\hline $\mathrm{R}^{2}$ & 0.3430 & 0.3495 \\
\hline$p$-value for F-test & 0.0000 & 0.0000 \\
\hline Impact of property rights protection ${ }^{4}$ & 0.080 & 0.034 \\
\hline
\end{tabular}

Notes:

1. Standard errors, clustered at the industry-city level, are reported in the bracket; *, **, *** represent significance at $10 \%, 5 \%$, and $1 \%$, respectively.

2. Number of suppliers was specified as its difference from the sample mean.

3. Entry barriers was specified as its difference from the sample mean.

4. Impact as measured by a one standard deviation increase in Property Rights Protection at the mean value of Suppliers/Entry barriers. 
Table 7. Robustness checks

\begin{tabular}{|c|c|c|c|c|c|}
\hline $\begin{array}{l}\text { Estimation specification } \\
\text { Sample }\end{array}$ & $\begin{array}{c}\text { (i) } \\
\\
\text { Total factor } \\
\text { productivity } \\
\text { (fixed } \\
\text { effect) }\end{array}$ & $\begin{array}{c}\text { (ii) } \\
\text { OLS } \\
\text { Whole } \\
\text { Total factor } \\
\begin{array}{c}\text { productivity } \\
\text { (LP) }\end{array}\end{array}$ & nple & $\begin{array}{c}\text { (iv) } \\
\text { Quantile }\end{array}$ & $\begin{array}{c}\text { (iv) } \\
\text { OLS } \\
\text { Private firm }\end{array}$ \\
\hline Property rights protection & $\begin{array}{l}0.178^{\star \star} \\
{[0.085]}\end{array}$ & $\begin{array}{l}0.153^{\star} \\
{[0.083]}\end{array}$ & & $\begin{array}{l}0.263^{*} \\
{[0.141]}\end{array}$ & $\begin{array}{l}0.302^{\star \star} \\
{[0.130]}\end{array}$ \\
\hline Litigation & \multicolumn{5}{|c|}{$\begin{array}{l}0.178^{*} \\
{[0.103]}\end{array}$} \\
\hline Controls & & & & & \\
\hline Enterprise characteristics & Yes & Yes & Yes & Yes & Yes \\
\hline CEO characteristics & Yes & Yes & Yes & Yes & Yes \\
\hline Industry dummies & Yes & Yes & Yes & Yes & Yes \\
\hline City dummies & Yes & Yes & Yes & Yes & Yes \\
\hline No. of observations & 1205 & 1205 & 1274 & 1369 & 1120 \\
\hline $\mathrm{R}^{2} /$ Pseudo $\mathrm{R}^{2}$ & 0.442 & 0.3211 & 0.3206 & 0.2020 & 0.3353 \\
\hline $\begin{array}{l}p \text {-value for F-test } \\
\text { Impact of property rights protection }\end{array}$ & 0.0000 & 0.0000 & 0.0000 & - & 0.0000 \\
\hline /litigation $^{2}$ & 0.036 & 0.049 & 0.036 & 0.084 & 0.097 \\
\hline
\end{tabular}

Notes:

1. Standard errors, clustered at the industry-city level, are reported in the bracket; *, **, *** represent significance at $10 \%, 5 \%$, and $1 \%$, respectively.

2. Impact as measured by a one standard deviation increase in Property Rights Protection or Litigation. 


\section{Appendix A. Geographic difference of property rights protection}

\begin{tabular}{l|c}
\hline & $\begin{array}{c}\text { (i) } \\
\text { Dependent } \\
\text { Variable: } \\
\text { Property rights } \\
\text { protection }\end{array}$ \\
F-tests & {$[1.28]$} \\
Industry dummies $=0$ & {$[15.03]^{\star \star \star}$} \\
City dummies=0 & Yes \\
Enterols & Yes \\
CEO characteristics & 1377 \\
\hline No. of observations & 0.1114 \\
\hline $\mathrm{R}^{2}$ & \\
\hline
\end{tabular}

Notes:

Standard errors, clustered at the industry-city level, are reported in the parentheses; *, **, *** represent significance at $10 \%, 5 \%$, and $1 \%$, respectively. 


\section{Appendix B. Population as a proxy for property rights protection}

During the late Qing Dynasty (1840-1911), China was defeated in a series of wars against foreign colonial powers, including two Opium wars with Britain, the Sino-Japanese War of 1894-95, and the Boxer Rebellion. In the wake of military defeats, the Qing government was forced to sign unequal treaties, conceding huge amounts of reparations as well as territorial and other concessions. For example, following the Boxer Rebellion, eight colonial powers attacked Beijing and forced the Qing government to sign the Peace Treaty of 1901, which stipulated reparations of 450 million taels of silver (Fan, 1955).

The total amount of reparations over 1840-1911 amounted to 30 times the annual treasury income in 1840 or 15 times the annual treasury income in $1890(\mathrm{Li}, \mathrm{Li}, \mathrm{Li}$, Yang, and Gong, 1994). In order to finance the war reparations, the Qing government imposed levies and taxes on the population, while delegating responsibility for collection to regional governors. Given the right to collect revenues, however, the regional governors seized the opportunity to determine the size of levies and taxes, leading to variations in taxation across China's regions.

In 1911, the Qing Dynasty was overthrown and a republican government was established in Nanjing. The new government enacted statutes providing for the protection of private property (Dong, Zhang, and Jiao, 2000). However, the republican government failed to secure national unity. Following the death of President Yuan Shih Kai in 1916, China split into north and south, with each part further divided into various regions.

The regional authorities were called "warlords" as they maintained their own armies and fought against rivals and one another. Regional wars caused widespread depredation of agricultural and other land. The warlords further increased taxes and levies to finance their expenditures. In some regions, after 1911, land taxes increased by over $50 \%(\mathrm{Li}, \mathrm{Li}, \mathrm{Li}$, Yang, and Gong, 1994). The incessant fighting and the increasing burden of taxes and levies prompted internal migration of people away from war-ridden regions. This led to the concentration of population and wealth in areas that offered better security of person and property (Wu, 1955). ${ }^{15}$

Accordingly, the population of a city in 1918-19 could reasonably reflect the state of property rights at that time, with a larger population indicating better protection of property rights. ${ }^{16}$

\footnotetext{
${ }^{15}$ See Rawski (1989) for the overall economic history of China during the Republican period.

${ }^{16}$ Superficially, our argument may appear to differ from that of Acemoglu, Johnson, and Robinson (2002), who argued that high population density in 1500 was correlated with weak property rights institutions.
} 
However, the underlying theory is the same. In Acemoglu, Johnson, and Robinson (2002), high population density was a precondition for expropriation. By contrast, we use population to reflect the equilibrium state of property rights. 